\title{
The Character Values-Based Folklores as Teaching Resources to Support English Acquisition
}

\author{
Siti Rochmiyati ${ }^{*}$ \\ Imam Ghozali ${ }^{2}$ \\ Luky Tiasari \\ ${ }^{1}$ Indonesian Language and Literature Education Department, \\ Universitas Sarjanawiyata Tamansiswa, Indonesia \\ ${ }^{2}$ Educational English Department, \\ Universitas Sarjanawiyata Tamansiswa, Indonesia \\ ${ }^{*}$ Corresponding Author
}

Doi: 10.36941/jesr-2020-0056

\begin{abstract}
The purpose of this study was to identify the folklores carrying character values as teaching materials in English acquisition in Indonesia. This exploratory study was conducted in Central Java and Yogyakarta provinces, Indonesia by inviting 139 participants of Junior high school teachers, students, and experts. The data was collected through interview, documentation and observation, and analyzed descriptively using the Miles, Huberman, E Saldaña' scheme, namely data collection, data condensation, data presentation and conclusion (2014). The result obtained 208 folklores categorized as fairytale, legend, and myth. By applying the Processability Theory (Pienemann, 2005), the researchers proposed some ideas in using the folklores which carry character values for supporting the English acquisition among junior high school students in Indonesia. Through an English integrated teaching and learning process, the students not only learnt the moral values from the folklores but also studied and acquired English as their foreign language. The students, who have been familiar with folklores from their hometown, possessed confidence in understanding the main idea of the story though it was written or told in English. They mostly learnt as well as acquired phrasal and lexical morphology of English.
\end{abstract}

Keywords: character values, folklore, English acquisition

\section{Introduction}

\subsection{Character Education}

Since 2010, the Indonesian Ministry of National Education has declared the 18 Culture and National Character Education values namely religiosity, honesty, tolerance, discipline, hard work, creativity, independence, democratic values, curiosity, nationalism, patriotism, achievement appreciation, communicative, peace, reading fond, environmental awareness, social awareness, and responsibility (Kemdiknas, 2011). Those characters have been formulated by considering the students relationships with God, themselves, family, society and environment. Through the national curriculum 2013, the 
students have been introduced with several teaching materials adopted from those 18 values. Based on Ki Hadjar Dewantara's educational concept that national character building is affected by teaching strategies (Majelis Luhur Persatuan Tamansiswa, 2013), this means that teachers play significant roles in shaping the students' characters. Building those characters through indoctrination has not been flourish anymore due to the unfertilized of the students' creativity. Furthermore, the indoctrination opts out the humanistic-affective approach which is mostly applied in Indonesian schools (Hartono et al., 2018).

Some researcher believe that teachers should start by building the nationalism values to the students as the nationalism spirit has faded away among the young generation (Satriawan, 2012). However, others prefer to mix several values into one integrated learning materials. On this position, Rohmiati (2015) suggests that the learning materials chould include various facets of Indonesia such as its geography, nature and legacy.

\subsection{Character Values-Based Folklores}

Folklore is a story about culture, history, or place which is originally passed down orally from one generation to the next generation existed in certain society (Smith, 2015) which most of them are not documented in the written form (Satriawan, 2012); (Danandjaja, 1995). The forms of folklore vary in fable, myth, and legend. As the story is told orally, many folklores often vanish since no more people retell the story to their children anymore. The folklore brings various values such as religiosity, patience, togetherness, bravery, ethics, compassion, determination, and beauty (Musdalifah, 2016). Junaidi (2017) identified some character values found in seven Andai-Andai folklores, existed in Kedurang District, Indonesia, such as religiosity, hard work, creativity, and discipline. In Kedurang, the Andai-Andai folklores are introduced in literature subject in elementary schools since most of the main characters in these folklores are children and animals.

In their study, Baiduri et al. (2019) found that most school students in Sumatra forget those Malay folklores through which 74 character values are introduced such as religiosity, tolerance, and social awareness. This previous research suggested to integrate the Malay folklores into school curriculum. In the classroom, the teachers may introduce the Malay folklores into drama, film or video which are depicted to interesting and fun learning model to the students.

\subsection{Problem of Research}

Considering the characteristics of folklores which are generally in spoken forms, it is a must to document them into written forms. In Indonesia, nowadays, some book publishers have started to release folklores into pictorial books, simplified books, and comics for supporting the folklore preservation. Indeed, business perspective cannot be taken apart. Children, as the main customers, especially love pictures and images in the books. The colorful and attractive book covers, for sure, attract the children to have a look inside the book. Additionally, television in Indonesia is also taking a part in introducing Indonesian folklores through short movies and segments.

The flourish of folklores, subsequently, place them as reading materials in Bahasa Indonesia subject taught in elementary to junior high schools in Indonesia. Another consideration in bringing folklores into school reading texts is because students can learn Indonesian cultures and moral values carried. However, folklores are mostly introduced in Bahasa Indonesia subject. Again, this is because folklores are passed orally in Bahasa Indonesia and other native languages in Indonesia. Indeed folklores can be used for attracting students in learning English (Yang, 20o8) without ignoring the cultural and moral values absorbed (Blyznyuk \& Nafalska, 2017) into interesting ways (Haratyk \& Czerwińska-Górz, 2017) Through folklores written in English, students not only learn the culture and values but also English features notably vocabulary, and syntactical structure in contexts (Warta, 2012). Moreover, teachers also have a great chance to introduce other cultures for building the students' social awareness (Kakampoura et al., 2017). 
Unfortunately, in Indonesia, not many teachers prefer folklores as a part of their English teaching materials. Most of them generally pick the texts provided on the subject text books. The reading passages in English text-books mostly displays based on the tense structures sequently started from Simple Present Tense, Past Tense, Progressive Tense and Perfective Tense with various topics which are closed to the learners' daily lives and experience.

\subsection{Research Focus}

Choosing the appropriate reading texts or listening materials in English learning process affects greatly on the students' vocabulary inventory and syntactical patterns understanding. The students learn how language and culture relate each other dynamically (Mzimela, 2016). The students pick up and analyze words and expressions from the folklores which commonly are different from those they use daily. Besides, the students can still grasp the moral values carried for establishing their characters. Through the folklore passages, the students may also express themselves socially by understanding their cultures (Bulut \& Bars, 2013), (Oguma, 2016). This means that it is very possible bringing folklores into the school system (Okediji, 2017).

The present study is designed to map the folklores existed in two provinces in Indonesia, Central Java and Yogyakarta. The results of this mapping are, then, analyzed with the respect of the English acquisition features and character building values introduced to junior high school students. The current research is basically depicted to the preliminary research of integrating folklores into English subject for supporting the English acquisition as the foreign language in Indonesia without ignoring the national character building set by the government. The further research will be also designed to create the integration of English-presented folklores into technology.

\section{Research Methodology}

The current exploratory study on folklores existed in Central Java and Yogyakarta provinces, Indonesia invited 139 participants from 6 junior high schools from both provinces equally. The participants consisted of 48 teachers, 46 students, and 45 Javanese folklores experts. The schools participated in this study were State Junior High School 5 Bantul, State Junior High School 4 Kulon Progo, State Junior High School 5 Gunung Kidul, State Junior High School 1 Ngluwar Magelang, State Junior High School 1 Jogonalan Klaten, and State Junior High School 5 Kebumen.

The data was collected through observation, documents, and interview. The researcher did observation as well as documents on the use of folklores in teaching and learning process in the selected schools before doing the interview with all participants. The documents required in the present study were textbooks, worksheets, library references. The obtained data was analyzed descriptively by following the (Miles et al., 1994) and (Tavakoli \& Esmae'li, 2013) steps; data collection, data reduction, data presentation and conclusion.

For gaining the national character values found in folklores in Central Java and Yogyakarta, Indonesia, the research designed a rubric as follows:

Table 1. The Rubric of Folklore Character Values

\begin{tabular}{ll}
\hline Character Values & Indicators \\
\hline 1. Religiosity & Perform worship \\
& Stick to religious teachings \\
& Follow the religious teachings \\
& Be grateful for God's gift \\
& Respect others \\
& Do not obtrude \\
2. Tolerance & Be open-minded \\
& be patient \\
& be helpful and generous \\
& Never compare one to another \\
& \\
& \\
&
\end{tabular}




\begin{tabular}{l}
\hline Character Values \\
\hline 3. Peace \\
4. Environmental awareness
\end{tabular}

5. Nationalism

6. Patriotism

7. Discipline

8. Honesty

9. Responsibility

10. Achievement Appreciation

11. Hard work

12. Curiosity

13. Creative

14. Reading Fond

15. Communicative

16. Independence
Indicators

Create a calm, safe, and peaceful atmosphere

Dispel a commotion

Avoid violence

Show a harmony

Maintain peaceful atmosphere

Do not differentiate among religion, ethnicity, and race.

Take benefits of environment without causing damage

Reuse and recycle

Maintain the nature

Preserve environmental cleanliness.

Keep and preserve culture, customs and traditions.

Respect for culture and country.

Uphold the culture and country.

Place the public interest above

Defend the nation

Loyal to the country

Sacrifice for the country

Follow and obey the rules

Give sanctions for the offenders

Carry out duties and obligations consistently

Express sincere feeling

Say frankly

Do not cover up lies.

Provide trusted evidence

Be brave as a right attitude

Do the duties and obligations. seriously

Keep fairness

Keep promises

Keep your promises that have been set.

Do apology

Be able to take right choices

Respect others works

Appreciate others achievement

Do not underestimate others.

Work hard to reach the goal

Struggle and pray for achieving the target

Create useful things

Never give up.

Believe in efforts planned

Be curious

Never give up in searching the answers

Be open-minded in learning

Develop useful things

Think critically

Do innovation

Be confident

Love reading

Be interested in books

Love searching detail information and writing

Have curiosity and think critically

Be broad-minded

Use the language properly and correctly.

Show polite attitude.

Be adaptable

Never underestimate others.

Do not depend on others

be responsible

believe in self capabilities

solve problem independently

Show strong character

Never give up 


\begin{tabular}{ll}
\hline Character Values & Indicators \\
\hline 17. Democratic Values & Be open-minded \\
& Be fair and wise \\
& Never cheat. \\
& Discuss all problems \\
& Respect the decisions \\
& Have gentle attitude and solidarity \\
& Be sympathy and empathy \\
& Be sincere and helpful \\
B. Social Awareness & Be generous sensitive \\
& work together \\
& Have affection, attention, humility, and loyalty to others.
\end{tabular}

The experts have validated the above rubric by considering the 18 character values formulated by the Indonesian Ministry of Education and Culture.

\section{Research Results}

The data showed that Central Java and Yogyakarta provinces in Indonesia had 208 folklores spread in 6 regencies. The insight data can be seen clearly on the table below.

Table 2. Type of Folklore Found in Central Java and Yogyakarta Provinces

\begin{tabular}{lcccc}
\hline \multirow{2}{*}{ Regency } & \multicolumn{3}{c}{ Type of Folklore } \\
\cline { 2 - 5 } & Fairytale & Legend & Myth & Total \\
\hline Bantul & 6 & 24 & 4 & 34 \\
Kulon Progo & 5 & 27 & 4 & 36 \\
Gunungkidul & 6 & 30 & 3 & 39 \\
Magelang & 3 & 30 & 1 & 34 \\
Klaten & $\mathbf{2}$ & $\mathbf{2 9}$ & $\mathbf{2}$ & 33 \\
Kebumen & 4 & $\mathbf{2 7}$ & $\mathbf{1}$ & 32 \\
Total & $\mathbf{2 6}$ & $\mathbf{1 6 7}$ & $\mathbf{1 5}$ & $\mathbf{2 0 8}$ \\
\hline
\end{tabular}

Among the 6 regencies involved in the current study, the highest and the lowest number of folklores were existed in Gunung Kidul and Kebumen with 32 and 39 folklores respectively. Whereas, the four other regencies supported between 33 and 36 folklores. The 208 total amount of folklores found were classified into three with legend (167) was the highest followed by fairytale (26) and myth (15).

Table 3. Character Values in Folklore Base on Regencies at Central Java and Yogyakarta Province

\begin{tabular}{|c|c|c|c|c|c|c|c|c|}
\hline & \multirow[b]{2}{*}{ Character Values } & \multicolumn{6}{|c|}{ The Number of Folklore } & \\
\hline & & Bantul & $\begin{array}{l}\text { Kulon } \\
\text { Progo }\end{array}$ & $\begin{array}{c}\text { Gunung } \\
\text { Kidul }\end{array}$ & Magelang & Klaten & Kebumen & \\
\hline 1. & Religiosity & 7 & 9 & 8 & 5 & 14 & 4 & 47 \\
\hline 2. & Nationalism & 7 & 6 & 9 & 8 & 2 & 9 & 41 \\
\hline 3. & Environmental awareness & 4 & 11 & 5 & 3 & 10 & 7 & 40 \\
\hline 4. & Patriotism & 7 & 12 & 5 & 2 & 7 & 6 & 39 \\
\hline 5. & Responsibility & 12 & 2 & 4 & 2 & 5 & 7 & 32 \\
\hline 6. & Social Awareness & 7 & 3 & 4 & 3 & 8 & 6 & 31 \\
\hline 7. & Achievement Appreciation & 9 & 7 & 3 & 4 & 1 & 4 & 28 \\
\hline 8. & Hard work & 3 & 5 & 1 & 1 & 3 & 6 & 19 \\
\hline 9. & Communicative & 1 & 4 & 2 & 2 & 5 & 1 & 15 \\
\hline 10 & Honesty & 5 & 2 & 1 & - & 1 & 5 & 14 \\
\hline 11. & Tolerance & 3 & 2 & - & - & 2 & 6 & 13 \\
\hline
\end{tabular}




\begin{tabular}{|l|l|c|c|c|c|c|c|c|}
\hline \multirow{2}{*}{ Character Values } & \multicolumn{7}{|c|}{ The Number of Folklore } & \\
\cline { 2 - 9 } & Bantul & $\begin{array}{c}\text { Kulon } \\
\text { Progo }\end{array}$ & $\begin{array}{c}\text { Gunung } \\
\text { Kidul }\end{array}$ & Magelang & Klaten & Kebumen & \\
\hline 12 & Discipline & 4 & 1 & 1 & 1 & 4 & 2 & 13 \\
\hline 13 & Creativity & 8 & - & 2 & - & 1 & 2 & 13 \\
\hline 14 & Curiosity & 2 & 2 & 2 & 2 & 1 & 3 & 12 \\
\hline 15 & Democratic Values & - & 3 & 1 & 2 & - & 6 & 12 \\
\hline 16 & Independence & 1 & 3 & 3 & 1 & 2 & 1 & 11 \\
\hline 17 & Peace & - & 4 & 2 & - & 3 & - & 9 \\
\hline 18 & Reading Fond & $\mathbf{1}$ & - & - & - & - & - & 1 \\
\hline & Total & $\mathbf{8 1}$ & $\mathbf{7 6}$ & $\mathbf{5 3}$ & $\mathbf{3 6}$ & $\mathbf{6 9}$ & $\mathbf{7 5}$ & $\mathbf{3 9 0}$ \\
\hline
\end{tabular}

The data above shows that folklore which carries religiosity places the highest number with 47 folklores spread in 6 regencies, i.e. Bantul (7), Kulon Progo (9), Gunung Kidul (8), Magelang (5), Klaten (14), and Kebumen (4). The very interesting one is that reading value is only showed by one folklore from Bantul entitled Ki Ageng Suryomentaram, the $55^{\text {th }}$ prince of Sultan Hamengku Buwana VII, the King of Yogyakarta. Based on this folklore, the prince Ki Ageng Suryomentaram had a high interest in books. He loved reading history, philosophy, psychology, and religious books. He also took English, Dutch and Arabic languages courses.

\section{Discussion}

The integration of local folklore in English subject taught in junior high school might be valuable in building the 18 students' characters as proposed by the Ministry of Education and Culture as well as the students' English acquisition.

A folklore entitled King Agung from Mataram Kingdom from Bantul regency, for example, told about the king habit in doing Friday Prayer in Mekkah, the Holy City of Moslems in Arab. This is illogic, however, this actually carries a moral message that Islamic followers must do a worship Jummah Prayer on Fridays as a part of their obedience on the Islamic teachings. In other words, King Agung from Mataram Kingdom folklore bring the religious character building. Another example is Umbul Sigedang folklore from Klaten. Umbul means a water spring. When the Dutch Army occupied Indonesia, they built irrigation channels from the spring to the Dutch sugar cane factory in Ceper, Klaten. The construction of the irrigation channel was very environmental friendly without cutting many trees. Along the channel, farmers also got the benefit from the channel for the field irrigation. Thus, the water spring Umbul Sigedang was used not only for business but also for society without destroying the nature. From the two examples above, either teachers or students can analyze and adopt the folklores moral values into lives. Besides, folklores in English can also be used to promote the English acquisition.

Linguistically, Past Tense forms are used frequently in folklore as it talks about something in the past. In Indonesia, generally, Past Tense materials in English subject are closed to the students' past lives such as their lives when they are children, their past holiday, their past sweet memory and many more. Some are taken from a short story or English simplified story such as Snow White, and Bears and Dragon.

Unfortunately, many Indonesian learners face difficulties in understanding the Past Tense grammatical structures. Even, students majoring English often face difficulties in acquiring this past patterns. English. Widyastuti (2015) found that among 27 university students majoring English in Yogyakarta, there were only two students who passed Stage 2 of Processability Theory English acquisition development. The interesting finding of the study was that most participants were very difficult in arranging Past-ed structure required on Stage 2, the phrasal morphological development of the Processability Theory. Based on the Processability Theory, the language learners follow lexical, phrasal, and inter phrasal developmental stages morphologically which cannot be jumped each other 
(Pienemann, 2005). This means that learners cannot acquire the higher stages before passing the lower stages. Another research on the similar finding was done in 2010 among three Indonesian family members who had been living in Australia for one year. The father was a master student who had been learning English formally for around 10 years and 3 month English intensive course before departing to Australia. The mother was a housewife who had learnt English for 10 years formally at schools. The daughter took an English course in Indonesia before going to Australia. The study found that even though both father and mother received their formal English learning, they hardly produced Past -ed patterns in their conversation (Zhang \& Widyastuti, 2010).

By considering the both previous research on the English acquisition, the structure of Past -ed seems very difficult to be acquired among Indonesian learners. One of the reasons is because the structure of expressing the past events in Bahasa Indonesia and English are different. In Bahasa Indonesia, past events are marked by time markers such as sekarang (now), kemarin (yesterday), besok (tomorrow) without changing the main verb, while in English the verb form is altered based on the tense or time (Widyastuti, 2015). Therefore, for helping learners in acquiring the Past Tense, the English teaching and learning materials must be closer to the students' backgrounds socially and integrated in English macro skills practices.

As the learners have already been familiar with the folklores around their regencies, bringing folklores into English learning materials help students in gaining their confidence in understanding the story. By applying a Task-based Learning (Willis, 1996), for instance, the students on the Pre-Task stage share their own background knowledge on Gua Nagabumi folklore from Bantul Regency. It carries a discipline character portrayed on the main character named King Panembahan Senopati from Mataram Kingdom who was just and wise. The Pre-Task stage is then followed by the Report and Reading Task, that is reading the Gua Nagabumi folklore. During the reading, the students work in pair for searching, listing and analyzing the education characters found in the selected folklore. Finally, the last stage, Language Stage, the teacher points the grammatical patterns the students found from the read folklore.

In facts, the students recognize the past forms not only from the reading form, but also from other macro skills namely speaking, listening and writing. The integrated and frequent used of past pattern in those English macro skills, for sure, make the students be familiar with. Reading and listening tasks are used for gaining input on the past forms. Meanwhile, speaking and writing are for the past form production practices. This is understandable as the students must have various practices which make them to use the language naturally. A Strategy Inventory for Language Learning Strategy (SILL) Version 7.o (Oxford, 1990) study on 26 new university in Indonesia students found that most participants preferred to use cognitive English learning strategy rather than other strategies (Widyastuti \& Gemilang, 2019). The cognitive strategy comprises of four sub strategies namely practicing, receiving and sending messages, analyzing and reasoning, and creating structure for input and output. The practicing sub strategy became the most popular among the $81 \%$ participants who chose cognitive strategy. This means that the typical of the learners was still beginners. They did repetition, practiced the linguistic systems, recognized and used the grammatical patterns and formulas.

Besides supporting the phrasal morphological acquisition, folklores also prospect in supporting the lexical acquisition. This refers to the learner vocabulary inventory. By listening to a recorded folklore, for example, the students have to take notes some new and difficult words and phrases which are discussed together with the teacher later on. The language production practices such as in speaking and writing help the students to restore and recall the new vocabulary they gain from listening exercises. In this case, again, the integrated model is required to make the students be familiar with the vocabulary.

Therefore, both phrasal and lexical morphological development acquisition discussed above basically can be fulfilled by integrating the folklores into the English teaching and learning formally in the classroom. Those should be presented spirally so that the students can grasp and produce the language actively in speaking and writing. Empirically, second or foreign language learners reach the 
acquisition gradually if they are familiar with the patterns through various tasks and forms cyclically in the syllabus (Skehan, 1996; Veselinovska et al., 2011). Similarly, Ostovar-Namaghi \& Gholami (2018) found that the learning materials compiled spirally affected on the students in understanding the materials cognitively and built positive impacts psychologically such as reducing anxiety and increasing the motivation.

\section{Conclusions and Perspectives of Further Research}

English as a foreign language in Indonesia still becomes a never ending interesting phenomenon to be discussed. On one hand, the government wish to increase the nationalism as well as other character values among young learners by introducing more folklores in Bahasa Indonesia subject. It might be true that learners successfully identify and adopt the character values set by the Indonesian Ministry of Education and Culture, however, it would be more interesting if the folklores also exist in English subject. There are at least three benefits can be gained. The learners can gain their confidence in reading the folklores as they have ever heard the selected folklores. The learners are still able to learn the character values seen on the folklores. Last, they can learn and acquire English as their foreign language morphologically. As a very limited research on the English acquisition among Indonesian learners using Processability Theory, further research on this field is still required. Another prospective further research is creating interesting or interactive media using technology for preserving the local folklores. The media can be the teaching and learning media attached on the English subject formally at schools.

\section{References}

Baiduri, R., Puspitawati, Khairani, L., \& Khasanah, R. (2019). The Existence of Malay Folklore in Medan. Proceedings of the and International Conference on Social Sciences and Interdisciplinary Studies. https://doi.org/https://doi.org/10.4108/eai.24-10-2019.2290587

Blyznyuk, T., \& Nafalska, K. (2017). Using of Folk Art to Enhance Learning at English Lessons in Primary School. Journal of Vasyl Stefanyk Precarpathian National University, 4(1), $155^{-161 .}$ https://doi.org/10.15330/jpnu.4.1.155-161

Bulut, M., \& Bars, M. E. (2013). The Role of Education as a Tool in Transmitting Cultural Stereotypes Words (Formal's): The Case of "Kerem and Asli" Story. Online Submission, 3(15), 57-65.

Danandjaja, J. (1995). A Comparative Study of Japanese and Indonesian Folklores. Journal Southeast Asian Studies, 33(3), 202-214.

Haratyk, A., \& Czerwińska-Górz, B. (2017). Folk Art and Culture in the Historical and Educational Context. CzechPolish Historical and Pedagogical Journal, 9(2), 31-45. https://doi.org/10.5817/cphpj-2017-0011

Hartono, Y., Haryanto, S., \& Asrowi. (2018). Character Education in the Perspective of Humanistic Theory: A Case Study in Indonesia. EDUCARE Journal for Educational Studies, 10(2), 95-108.

Junaidi, F. (2017). The Value of Character Education in Andai-Andai Folklore and Its Use As Learning Material for Literature Subject in Elementary School. The 3rd International Conference of Advances in Education Adn Education Sciences, 20-27.

Kakampoura, R., Katsadoros, G., Nounanaki, A., \& Kolokythas, D. (2017). Educational Activities Concerning Folk/Popular Culture in Greek Primary School Websites. European Scientific Journal, ESJ, 13(10), 246. https://doi.org/10.19044/esj.2017.v13n1op246

Kemdiknas. (2011). Pedoman Pelaksanaan Pendidikan Karakter. Puskur dan Perbukuan Balitbang Kementerian Pendidikan Nasional.

Majelis Luhur Persatuan Tamansiswa. (2013). Ki Hadjar Dewantara: Pemikiran, Konsepsi, Keteladanan, Sikap Merdeka. UST Press.

Miles, M. B., Huberman, A. M., \& Saldaña, J. (1994). Qualitative Data Analysis: A Methods Sourcebook. Sage Publications, Inc.

Musdalifah, A. (2016). Nilai-nilai Budaya dalam Tiga Cerita Rakyat Tolaki (Pendekatan Sosiologi Sastra. Jurnal Humanika, 16(1), 1-17. https://doi.org/10.1017/CBO9781107415324.004

Mzimela, J. (2016). Exploring the Role of Teaching Using Folklore in Developing Grade R Learners' Mother Tongue. Studies of Tribes and Tribals, 14(2), 129-137. https://doi.org/10.1080/0972639x.2016.11886740 
Oguma, M. (2016). The Study of Japan through Japanese Folklore Studies. Japanese Review of Cultural Anthropology, 16, 237-250. https://doi.org/10.1489o/jrca.16.o_237

Okediji, H. A. A. (2017). Effect of Oral Traditions, Folklores and History on the Development of Education in Nigeria, 1977 Till Date. Journal of History Research, 7(2), 59-72. https://doi.org/10.17265/2159550x/2017.02.001

Ostovar-Namaghi, S. A., \& Gholami, M. (2018). Exploring Language Teachers' Perceptions of Cyclical Presentation of Materials in an EFL Context: A Grounded Theory. English Language Teaching, 11(3), 6o-66.

Oxford, R. . (1990). Language Learning Strategies. Newbury House Publishers.

Pienemann, M. (2005). An introduction to Processability Theory. In Cross-linguistic aspects of Processability Theory (pp. 1-6o). John Benjamins.

Rochmiyati, S. (2015). Kebijakan Pendidikan Bahasa Indonesia dalam Perspektif Pendidikan Nasional. Jurnal Caraka, 1(2), 4-13.

Satriawan. (2012). Pendidikan (Karakter) Salah Kaprah.

Skehan, P. (1996). Second language acquisition research and task-based instruction. In J. Willis \& D. Willis (Eds.), Challenge and change in language teaching (pp. 17-30). Heinemann.

Smith, C. . (2015). Folklore and Children's Literature: A Content Analysis of the de Grummond Children's Literature Collection. SLIS Connecting, 4(2). https://doi.org/https://doi.org/DOI: 10.18785/slis.0402.07

Tavakoli, M., \& Esmae'li, S. (2013). The Effect of Using Print Media on Children's L2 Literacy Development: A Longitudinal Study. Journal of Language Teaching and Research, 4(3), $570-578$. https://doi.org/10.4304/jltr.4·3·570-578

Veselinovska, S. S., Gudeva, L. K., \& Djokic, M. (2011). The effect of teaching methods on cognitive achievement in biology studying. Procedia-Social and Behavioral Sciences, 15, $2521-2527$. https://doi.org/https://doi.org/10.1016/j.sbspro.2011.04.138

Warta, I. K. (2012). Developing Students' Moral Value Through Folklore in Multilingual Setting : A Case Study In The Development of Morality. The XIII Annual International Semianr on Ethics, Spirituallity, and Morality, 119.

Widyastuti, I. (2015). A Processability Theory Study: Past-ed Acquisition in University Learners in Indonesia. Ahmad Dahlan Journal of English Studies, 2(1), 78-84.

Widyastuti, I., \& Gemilang, A. V. (2019). A Trend in English Learning Strategy: A SILL Survey. The 5th International LLTC Proceedings, 112-116. https://doi.org/http://doi.org/10.24071/1ltc.2018.16

Willis, J. (1996). A framework for Task-based Learning. Pearson Education Ltd.

Yang, Y. (2008). The Importance of the Teacher for Developing Interest in Learning English by Chinese Students. International Education Studies, 1(1), 95-100. https://doi.org/10.5539/ies.vinıp95

Zhang, Y., \& Widyastuti, I. (2010). Acquisition of L2 english morphology: A family case study. Australian Review of Applied Linguistics, 33(3), 1-17. https://doi.org/10.2104/aral1029 